\title{
Trends in James Baldwin Criticism 2010-13
}

\author{
D. Quentin Miller Suffolk University
}

\begin{abstract}
The acceleration of interest in Baldwin's work and impact since 2010 shows no signs of diminishing. This resurgence has much to do with Baldwin-the richness and passionate intensity of his vision-and also something to do with the dedicated scholars who have pursued a variety of publication platforms to generate further interest in his work. The reach of Baldwin studies has grown outside the academy as well: Black Lives Matter demonstrations routinely feature quotations from Baldwin; Twitter includes a "Son of Baldwin" site; and Raoul Peck's 2016 documentary, I Am Not Your Negro, has received considerable critical and popular interest. The years 2010-13 were a key period in moving past the tired old formula-that praised his early career and denigrated the works he wrote after 1963-into the new formula-positing Baldwin as a misunderstood visionary, a wide-reaching artist, and a social critic whose value we are only now beginning to appreciate. I would highlight four additional prominent trends that emerged between 2010 and 2013: a consideration of Baldwin in the contexts of film, drama, and music; understandings of Baldwin globally; Baldwin's criticism of American institutions; and analyses of Baldwin's work in conversation with other authors.
\end{abstract}

Keywords: James Baldwin, literary criticism (2010-13), African-American literature, transnational, performance, film, drama, music

In Volume 2 of James Baldwin Review (2016), Lynn Orilla Scott surveyed trends in Baldwin criticism in the first decade of the twenty-first century. This essay picks up where Scott left off, and although it covers only one-third as much time, at least as much Baldwin criticism was published during this period as was published between 2001 and 2010. There has been a remarkable acceleration of interest in Baldwin's work, and the trend shows no signs of diminishing. The reasons for this

James Baldwin Review, Volume 3, 2017 @ The Authors. Published by Manchester University Press and The University of Manchester Library 
resurgence have much to do with Baldwin-the richness and passionate intensity of his vision-and also something to do with the dedication of the scholars who have pursued a variety of publication platforms to generate further interest in his work, such as the inauguration of this journal and special issues of African American Review and ANQ: A Quarterly Journal of Short Articles, Notes, and Reviews.

The reach of Baldwin studies has grown outside the academy as well: Black Lives Matter demonstrations routinely feature quotations from Baldwin; one of the more prominent Twitter sites is called "Son of Baldwin"; and Raoul Peck's 2016 documentary I Am Not Your Negro, based on an unpublished screenplay by Baldwin, has received considerable critical and popular interest, including a nomination for an Academy Award. If the seeds for this renaissance were sown in the two decades following Baldwin's death, they have sprouted like a magic beanstalk in the two decades since then. The years 2010-13 were a key period in moving past the tired old formula-that praised his early career and denigrated the works he wrote after 1963-into the new formula-positing Baldwin as a misunderstood visionary, a wide-reaching artist, and a social critic whose value we are only now beginning to appreciate.

Extending the reach of the inaugural conferences in London in 2007 and Boston in 2009, Baldwin scholars gathered for a biennial meeting in 2011, this time in New York City. This meeting, organized by Douglas Field and Rich Blint, was at least as large as the London and Boston conferences that had preceded it, and it took place at a variety of venues throughout Manhattan, involving public intellectuals like Herb Boyd and family members like Baldwin's niece Aisha KarefaSmart in addition to university-based academics. The growing cadre of Baldwin scholars had begun to mobilize at this point, organizing what would become an officially chartered author society in 2015 , also the year in which the inaugural issue of the James Baldwin Review appeared, and planning for a pair of conferences in 2014 and 2016, both in France. The overview I will provide here will cover criticism published between 2010 and 2013, but it is worth noting that the efforts of Baldwin scholars also preserve a tradition of in-person meetings that catalyzes such publications.

Scott identified some key trends in the 2001-10 period, including "new and diverse critical lenses [which] contributed to more complex readings of Baldwin's texts." She also pointed to a continuation of the trend for appreciation of Baldwin's lesser-known later works, and an understanding of his years in Turkey as opposed to the traditional focus on Baldwin's expatriation in France. Finally, she showed how new legal and historical readings of Baldwin helped to reread Baldwin in the contexts of the Civil Rights and Black Power movements. Some of these trends continued to flourish in Baldwin criticism of the next few years, but I would highlight four additional prominent trends that emerged between 2010 and 2013: a consideration of Baldwin in the contexts of film, drama, and music; understandings of Baldwin globally; Baldwin's criticism of American institutions; and analyses of Baldwin's work in conversation with other authors. 
One development in this era is a turn toward Baldwin and performance. The debate over Baldwin's genres had long involved a tug-of-war between those who regarded him primarily as an essayist and those who viewed him primarily as a novelist. He published roughly an equal number of volumes of each genre, and together they do constitute the bulk of his output, but scholars in the early twenty-first century had begun to explore his writings in lesser-known genres as well. Between 2010 and 2013 a significant number of essays appeared regarding Baldwin and the performing arts: music, drama, and film.

Music has frequently been a fertile context for Baldwin scholars who have taken their cue from his many works titled after, or patterned after, the blues. During this period, scholars began to move beyond readings of music within Baldwin's work, accounting instead for the way music connects his work to larger cultural or intellectual trends. Gerald David Naughton uses music to address what he sees as an oversight in Baldwin studies: that scholars have paid insufficient attention to Baldwin's influence on writers outside of American literature. He writes, "Much scholarship on his oeuvre centres on the literary models and other sourceswhether white or black - that contributed to the making of Baldwin as an artist, but notably few critics have extended this treatment beyond the borders of American literary history." 2 Naughton's reading of Baldwin and Caryl Phillips-the AfroCaribbean novelist who delivered the keynote address at the 2007 London conference-involves "musical structures, themes, and motifs" in the works of the two writers. ${ }^{3}$ Naughton's analysis is sophisticated in its theoretical basis and in its aim to counteract the trend of limiting Baldwin's sphere of influence to American writers, yet he still offers a fresh reading of “Sonny's Blues." In an essay in the 2013 special issue of African American Review, Carter Mathes reads one of Baldwin's less prominent texts, No Name in the Street, in terms of "sonic experimentation and improvisation."4 Another notable expansion of the critical understanding of Baldwin and music is Douglas Field's interview with the Belgian jazz composer David Linx in that same volume.

Although it is about more than music, E. L. Kornegay's 2013 book $A$ Queering of Black Theology: James Baldwin's Blues Project and Gospel Prose is a significant contribution in that it links music to both religion and sexuality. Kornegay's definition of the blues treats it as an expansive metaphor rather than a musical form: "Blues poetics is a reintegration of the black body-a blues sexualized body whose intimate nature is birthed through the intercourse of the spirit with surviving the trauma produced in an oppressed world." 5 Kornegay's study tends to theorize Baldwin rather than engaging directly in music theory; for example, "I interpret the blues ... as a hermeneutic

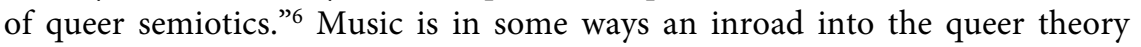
that Kornegay advances: "Baldwin uses the language of the blues to identify and explain black bodies on its own terms, thereby reclaiming the moral authority stripped away by puritanism and muted by homophobia."7 This analysis is far-reaching and densely packed with a number of ideas. One might recognize this complexity as a reflection of Baldwin's complexity, in contrast with others' 
critical attempts to isolate a single strand of Baldwin's thought and lift it out for examination.

Baldwin wrote three plays during his lifetime, including his unpublished final work The Welcome Table. Of the three, Blues for Mister Charlie has received the most attention. A number of substantial articles were published about this play during the period covered by this essay. In a cogent, insightful article in American Quarterly, Koritha Mitchell honors Baldwin's contributions to performance theory as articulated in selected essays, then uses that theory to arrive at a fresh reading of Baldwin's central play. Mitchell links Baldwin's conceptions of the theater's "life-changing power" reestablish human connection.

Soyica Diggs Colbert, in her 2011 book The African American Theatrical Body, includes a lengthy chapter on Blues for Mister Charlie. As part of her reading of African-American plays "as acts of recuperation and restoration, creating sites that have the potential to repair the damage slavery and its aftermath cause," Colbert contextualizes Baldwin's central play in a wholly original way. She reads the play as a response to the lynching of Emmett Till, but contends that it "also recalls the deaths of the many thousands that had already gone by giving an acoustic materiality to the victims of lynching." 10 While many other representations of lynching make use of the visual, Baldwin deliberately obscures Richard's death from the audience's view, and thus "calls attention to the aural history that has been overlooked by focusing on the visual evidence." 11 She regards the play as an important turning point in this regard since it enacts "an engagement of the abject, in attention paid to the notes off the scale." 12

Turning to another significant moment in Baldwin's theater history, in her article "In Another Country: James Baldwin and the Turkish Theatre Scene," Çigdem Üsekes elaborates on Magdalena Zaborowska's work on Baldwin in Turkey. Üsekes makes use of sources in the Turkish press that deepen an understanding of Baldwin's work in another dimension of theatrical production, as the director of a play during his years in Istanbul. She delves into original Turkish reviews of the play in order to widen the contextual frame for this once-overlooked chapter in Baldwin's artistic development.

Adding yet another dimension to studies of Baldwin's relationship to the theater is Shonni Enelow's article, "The Method and the Means: James Baldwin and the Actors Studio." Enelow analyzes Baldwin's extended satire of Lee Strasberg and method acting in Tell Me How Long the Train's Been Gone. Enelow points out that, "though it is little known and little remarked upon in either American theatre history or in Baldwin studies, Baldwin had a long and productive association with the Actors Studio, beginning in 1958, when the Studio tried out a dramatic version of Baldwin's novel Giovanni's Room." 13 The essay examines the Actors Studio production of Blues for Mister Charlie and Baldwin's scathing response in Tell Me How Long the Train's Been Gone not only to trace out his tempestuous relationship with the theater, but to say something broader about his "growing discontentment with liberal universalism." ${ }^{14}$ This article provides 
a necessary perspective in that it combines reception history with insight into method acting and Baldwin's understanding of it, which, according to Enelow, is deep and sophisticated.

Like his love/hate relationship with the stage, Baldwin had a similar response to the silver screen. Ryan Jay Friedman's essay "'Enough Force to Shatter the Tale to Fragments': Ethics and Textual Analysis in James Baldwin's Film Theory" provides a deep reading of The Devil Finds Work along with two of Baldwin's review essays. He shows an appreciation for Baldwin's critical skills, demonstrating how attuned he is to "the visual register of film" and admiring the way "Baldwin's film writings move fluidly between considerations of screenwriting, cinematography, acting, audiences, and reception and engage in detailed, sustained textual analyses of individual films." 15 Other readings of Baldwin's film criticism tend to dwell on its content: Friedman moves the critical conversation toward a technical understanding of Baldwin's achievement as a film critic.

Ed Pavličs essay "Speechless in San Francisco" offers a reading of the infrequently scrutinized film Take This Hammer about Baldwin's 1962 visit to San Francisco, and he connects this analysis to a later San Francisco film, Medicine for Melancholy (2009). Pavlić demonstrates the thematic influence Take This Hammer had over Medicine for Melancholy while offering informed cinematic analysis of both. Part of Pavlićs project here is recovery-not only of the importance of Take This Hammer, but of other overlooked writings by Baldwin of the mid-1960s - and part of it is a questioning of the rhetoric of those who described the United States as "post-racial" partway through the first term of the Obama presidency. He concludes, "The audience leaves Medicine for Melancholy with a sense that generations of Americans after Take This Hammer have lived amid wild alterations (demographic, cultural, technological, political) in the racial grain of experience."16

Two essays published during this period consider Baldwin's film project on Malcolm X, published as the "scenario" One Day When I Was Lost. Brian Norman's "Bringing Malcolm X to Hollywood" and my own essay "Lost and ... Found? James Baldwin's Script and Spike Lee's Malcolm X" consider the fate of Baldwin's original screenplay. Both essays address the curious path of Baldwin's misadventure in Hollywood, which he discussed in The Devil Finds Work, in an op-ed in The New York Times, and elsewhere. Norman's article regards One Day When I Was Lost as a "closet screenplay" whose journey "gauges the legacy of Malcolm X in the American cultural imagination." ${ }^{17}$ He compares Baldwin's script to the two more prominent renditions of Malcolm X's story-the coauthored Autobiography of Malcolm X and Spike Lee's 1992 film Malcolm X-and argues that Baldwin's "experimental script" utilizes "chronological dysphoria and protofeminist and queer elements" to "refuse a roadmap to a singular, inevitable version of Malcolm and racial progress." ${ }^{18}$ Norman's article and mine both triangulate Baldwin's version with the Autobiography and Spike Lee's film, but with different emphases. Whereas Norman's examines the way Baldwin's script offers complex alternatives to the main arc of the Malcolm X story-alternatives that 
Lee expunges-mine scrutinizes scenes from Lee's film, which are precisely the type of Hollywood cliché that Baldwin wanted to avoid after a screenwriter named Arnold Perl was hired to help "fix" Baldwin's work. Both essays ultimately argue that Baldwin's voice should be heard alongside the more popular renditions of Malcolm X's story.

The second category of Baldwin criticism I have identified during this period might be termed "the global Baldwin." This category builds on the traditional association of Baldwin with the expatriate experience, branching out into understandings of his expansive geographical imagination. Zaborowska's pioneering 2009 book on Baldwin in Turkey paved the way for considerations of Baldwin beyond Paris, the site of his early period of expatriation and the setting for much of his early work.

And yet, more work was done on Baldwin and Paris as well. Douglas Field's chapter on Baldwin in the collection Paris, Capital of the Black Atlantic (2013) is a compelling overview of Baldwin's complex relationship with the City of Lights, as expressed initially in the so-called Paris essays from Notes of a Native Son and as later revised-albeit with some crucial factual errors-in No Name in the Street. Field also includes a wholly original reading of Giovanni's Room by focusing on oceanic imagery in the novel. Resisting a claim by Paul Gilroy regarding the unity of black transnational culture, Field demonstrates how Baldwin's work illustrates how "transnational exchange is fraught with difficulties that arise from cultural and linguistic differences, a feature of his essays that has arguably obscured his significance as a transatlantic writer." 19 Field exposes the contradictions in Baldwin's Paris as the site of both personal and communal identity formation.

The most significant publication during this period that deals with the global Baldwin is the 2011 collection of essays James Baldwin: America and Beyond, edited by Cora Kaplan and Bill Schwarz, and based on selected proceedings from the 2007 conference in London. The editors begin the volume by acknowledging new directions in Baldwin criticism that seek to break down the binaries, realizing even that their subtitle might appear to fall into that same pattern; they argue, "In choosing [America and Beyond] we don't mean to imply any necessary given polarity between the two: between America and its others. As ever with Baldwin, the salient point-if invariably also the most contentious-resides in the conjunction." ${ }^{20}$ I shall devote substantial space to summarizing the content of America and Beyond because its essays demonstrate not only a critical willingness to understand Baldwin's global imagination, but also collectively illustrate a broadening of approaches to Baldwin's work.

The rich essays in this collection-including the eloquent introduction-build on Baldwin's American identity and Parisian revision of it, then move into new territory. Essays by Kevin Birmingham, Magdalena Zaborowska, and me connect Baldwin's works and experiences in America to his works and experiences abroad. Zaborowska's work involves a reading of Baldwin's unpublished final work The Welcome Table and connects her groundbreaking work on Baldwin in Turkey to a series of projects involving this play and the house in which Baldwin lived 
and worked in his final years. Even though she places The Welcome Table along a continuum of his earlier works, especially the plays, she also describes it as his "arguably least American work" 21 and suggests that publication and more critical exposure to it will further expand our understanding of Baldwin's global imagination. Birmingham revises critical renditions of Baldwin's paranoid view of the American South to focus on a broader idea of the challenges of private and public life in American culture and history. He argues, "Baldwin found the full depth of history's pockets not in the South, but in West Africa and Israel." 22 After surveying Baldwin's physical movements as well as intellectual quests for the type of useful memory engendered in the notion of ancestral homelands, he concludes, "Baldwin's endless commuting was not exactly the movement of a restless exile. Rather, it was a way to generate collective memory through something other than the centripetal pull of a diasporic homeland." ${ }^{23}$

In the same collection, essays by Cheryl Wall, Colm Tóibín, and Briallen Hopper examine Baldwin's American identity on levels of literary influence and language itself. Wall uses the Cold War as a way of defining the brand of American exceptionalism that emerged virtually at the beginning of Baldwin's writing career. Baldwin engages with the idea of American exceptionalism strategically, "to advance the scrupulously visible political interest of African Americans" while "arguing that the failure of his countrymen is the failure to acknowledge the burden of their own bloody history." 24 Tóibín ranges broadly across Baldwin's reviews and essays to paint a portrait of an artist whose influences were varied, complex, and unpredictable, riffing on an interview in which Baldwin cites Ray Charles, Miles Davis, and Henry James as his models for Another Country, then going on to show other passages where Baldwin's "style had not an ounce of James or jazz." 25 Tóibín's analysis widens our appreciation for Baldwin's range while also hinting at the author's limitations. Hopper goes deeper into literary influence by examining one of Baldwin's early targets, Harriet Beecher Stowe, as someone whose legacy troubled Baldwin beyond what he wrote in "Everybody's Protest Novel."

Also in James Baldwin: America and Beyond, Vaughn Rasberry, George Shulman, and Robert Reid-Pharr contemplate how the trajectory of Baldwin's career was affected by historical and political movements that connected and problematized America's relationship to the rest of the world. Rasberry reframes Baldwin's Cold War sensibility, which "encompasses the global anticolonial and Civil Rights movements, the onset of centrist liberalism, and the calamities of the Second World War," suggesting Baldwin's value beyond issues of national identity and race to include history more broadly, "the apocalyptic site of ghastly twentieth-century events that can be thought principally in terms of organized state crime." ${ }^{26}$ Shulman uses rhetorical analysis to connect Baldwin's use of prophecy to politics; he writes, "this secularized prophecy enacts registers of voice-urgent, intense, uncompromising, probing, accusatory, demanding, provoking-that are devalued or even demonized both by liberal discourse and by prevailing genres of political theory." 27 Reid-Pharr begins his meditation at a very early point in 
Baldwin's career-in a poem he published in high school-and contrasts this with his disparaged final work, The Evidence of Things Not Seen, to interrogate the very processes of canonization, arguing that "it is precisely within undervalued precincts that one might most easily discern basic social, aesthetic, and ideological structure." 28

Finally, essays by Douglas Field, Kevin Gaines, and Eleanor Traylor in Kaplan and Schwarz's volume consider Baldwin's relationship to Africa and African writers. A formative moment in this regard is Baldwin's account of the First Negro Writers and Artists Conference in 1956, described in the essay "Princes and Powers" and revisited in No Name in the Street. Gaines reads this moment as "a dangerous crossroads" and attributes Baldwin's turmoil to "the estrangement he, as a queer black man, was made to feel by his own people. The calculated mix of disclosure and dissemblance with which Baldwin references his sexuality in this recollection suggests an internal cold war waged against Baldwin by a younger generation of black militants." 29 He concludes that the conference "provides an important occasion for understanding Baldwin's evolution as a highly original commentator on racism, sexuality, and national identity." ${ }^{30}$ Field references the same conference in his essay "What Is Africa to Baldwin?," yet develops a broader argument about "Baldwin's complicated, shifting views on Africa" ${ }^{1}$ over the course of his career, ultimately leading to Baldwin's desire for greater dialogue between members of the African diaspora globally and reflecting his own "broader transcultural perspective." 32 Field mentions a meeting between Baldwin and Chinua Achebe, and the relationship between these writers is the subject of Eleanor Traylor's essay in which she places Things Fall Apart and Go Tell It on the Mountain into conversation.

The trend to globalize Baldwin studies between 2010 and 2013 was not limited to Kaplan and Schwarz's collection. The 2013 special issue of African American Review (AAR) devoted to Baldwin was full of essays on this topic. Alice Craven's essay in that issue connects Baldwin's film criticism to an interpretation of film representations of the contemporary Parisian banlieues, the French equivalent of the Harlem ghetto of Baldwin's youth. In his essay in the same issue of $A A R$ Christopher Winks goes further down the critical inroads made into Baldwin's response to Africa from Kaplan and Schwarz's collection, concentrating particularly on Baldwin's engagement with Négritude. In his essay "Britain is No Longer White': James Baldwin as a Witness to Postcolonial Britain,” Rob Waters considers Baldwin's commentary on England and its colonies-mainly in the Caribbeanto contrast "the difference between the operations of race and identity in the United States and their operations in Europe" 33 more generally, in Baldwin's mind. Hortense Spillers, in a characteristically insightful essay in Callaloo in 2012, revisits Baldwin's essays on the 1956 African Writers' Conference and concludes, "Baldwin, our modern-day Jeremiah, captures the brutal simultaneities and contrarieties that traverse the mid-century, when he pins his hopes on the prophetic potential of the American Negro." 34 In another expansion upon Zaborowska's work on Baldwin in Turkey, Kim Fortuny analyzes a little-known 1970 audio 
interview that Sedat Pakay conducted with Baldwin in Istanbul, an interview that remains unpublished. She argues that this interview "is more consciously global in scope than much of his writing" and calls the interview "an important example of the transnational reach of Baldwin's oeuvre, a dimension certainly addressed by Baldwin scholars, though often circumvented by many who take Baldwin at his all-American word." ${ }^{\prime 35}$ Fortuny summarizes the substance of this crucial text and also analyzes Baldwin's style as an interviewee.

Another 1970 interview with Baldwin, conducted in French and never before translated and published in English, was published in 2011 in Transition. Translator Peter Thompson frames the interview by providing some context: it was conducted by Nabile Fàres, an Algerian writer, in the French actress Simone Signoret's home. Recognizing not only a friendship between these two writers that has largely gone unnoticed, but also acknowledging Baldwin's prescience as a global thinker, Thompson writes that Another Country "reflects many of the issues of alienation and identity which Fàres-and many others in the Maghreb, sub-Sahara, and the United States-will write about in the years between 1970 and now." 36 The interview that follows is instructive in terms of the types of questions Baldwin was being asked in 1970 - about subjects like the blues, Black Power, and American literary history-and, of course, is valuable for his eloquent, honest responses.

One other notable publication during this period is James Baldwin in Turkey: Bearing Witness from Another Place, a collection of photographs by Sedat Pakay, edited and presented by Kathryn Hubbard and Barbara Earl Thomas. This collection provides a visual counterpart to the literary critical work on the global Baldwin that flourished between 2010 and 2013. Perhaps signaling a move toward more studies of the confluence between Baldwin and photography, Leah Mirakhor's essay in the special issue of $A A R$ combines analysis of Baldwin with the work of photographer Robert Adams. During his heyday Baldwin was among the most-photographed authors alive, and he also wrote the text to a collaborative book with Richard Avedon, Nothing Personal, in 1964. These works hint at Baldwin's contributions to the art of photography and complement the work on Baldwin and the performing arts described above.

A third category of works published during this period paints a portrait of Baldwin as a sophisticated social critic. In these works Baldwin scholars turn to some of the traditions or institutions that Baldwin critiqued, often going beyond the early familiar works and into the latter half of his career. Bill Lyne initiates this trend in a 2010 article that argues against the hackneyed take on Baldwin's career as being in decline after 1963; Lyne writes, "Baldwin's fall from literary grace coincides with his move from liberal integrationist orthodoxies to a more radical politics." ${ }^{37}$ Lyne reads The Fire Next Time and No Name in the Street-one of Baldwin's most celebrated works and one of his "most reviled and neglected"to unearth important questions regarding Baldwin's evolving political stance, misreadings of it, and ensuing questions of canonicity. ${ }^{38}$ In short, Baldwin's unacknowledged turn from liberalism to radicalism explains his critical decline more than does any perceived faltering of his powers. 
Moving from politics to the law, Shireen R. K. Patell "surveys the traumatic landscape of law, history, and literature" 39 in order to contextualize "Going to Meet the Man." The story becomes a new type of protest literature, in Patell's reading, as well as a "new production of history ... addressed to those "hidden laws' that institutional law perpetually fails to recognize." 40 Extending the scope of this study, particularly with regard to incarceration, Melinda Plastas and Eve Allegra Raimon's article "Brutality and Brotherhood: James Baldwin and Prison Sexuality" considers "prisons as important sites of political struggle," 41 particularly in Baldwin's work of the early 1970s.

My 2012 book "A Criminal Power": James Baldwin and the Law extends this inquiry in order to look at Baldwin's entire career in the context of the law. This work is the first non-biographical book-length study to discuss Baldwin's entire oeuvre rather than parts of it limited by genre or by a period of his career. The narrative I trace begins with Baldwin's despair in the budding years of his career when he was arrested for a petty crime in Paris and, after spending eight days in prison, attempted suicide. Baldwin's response to the law represents a journey from intimidated fear, to recognition that the law itself constituted "a criminal power," and finally to empowerment as he finds the ability to control the law by assuming a lawyerly voice and methodology in his final work of non-fiction, The Evidence of Things Not Seen. Using critical race theory as a framework, A Criminal Power traces this journey as a way of fusing a number of Baldwin's concerns that recur throughout his career, from corrupt police officers to botched trials, and from the effects of civil rights legislation to the consequences of wrongful imprisonment. I conclude, “Baldwin's career is instructive not as the final word about how to cope with racism in legal contexts, but rather as a reflection of the value of emotional and intellectual struggle when such racism presents itself." 42

In his work American Oracle about the convergence of the centennial of the Civil War and the Civil Rights movement, David Blight devotes an important chapter to Baldwin, whose voice Blight posits as a contrast to the host of thinkers who saw the occasion as a cause for celebration and commemoration. Basing his argument on Baldwin's tricky balancing act between private artist and public spokesman, Blight writes, "Although he hardly needed to declare it explicitly, Baldwin made himself into an alternative African American voice responding to the cacophony and orthodoxy of Centennial popular culture." 43 Baldwin is cast here as a historian who "embodied" the long aftereffects of the Civil War as "a deeply internal battle against the fear and rejection caused by racism, homophobia, and what he came to analyze as America's mythic sense of its own invulnerable, self-righteous, unexamined or even unknown history." ${ }^{4}$ In addition to being a vital critic of institutions in his own time such as the law, Baldwin is figured here as a sophisticated historian even though he did not write directly about the Civil War in any sustained way. Rather, his subject, as Blight sees it, is the way Americans imagine the past, often distorting it in the name of national mythology.

The fourth major development I have identified in Baldwin scholarship from 2010 to 2013 is a willingness to consider his career in conjunction with other 
authors and artists. Earlier periods of criticism were consumed by Baldwin's battles with the literary giants who preceded him-such as Harriet Beecher Stowe, William Faulkner, and especially Richard Wright-or his contemporaries who took swings at him, such as Norman Mailer, Eldridge Cleaver, and Ed Bullins. In the early twentieth century, critics began to take note of writers, intellectuals, and artists who were more complementary to Baldwin's vision, such as Toni Morrison: a 2006 essay collection by Lynn Scott and Lovalerie King focuses entirely on the works of these two authors in artistic conversation. A number of these articles were published in a special issue of $A N Q$ in 2011 as a cluster of essays collectively entitled "James Baldwin and Influence."

The tendency to pair Baldwin with other writers expanded considerably during this period. A number of critics focused on other literary predecessors than the ones listed above, from the unlikely (Henry Roth) to the recurrent (Henry James). My article on Baldwin and Hemingway in Charles Scruggs's collection, Hemingway and the Black Renaissance, discusses how the myth of Paris as an ideal expatriate colony for the American writer is tested in Baldwin's first work of non-fiction and Hemingway's last, A Moveable Feast. Scruggs in the same volume reads Hemingway's influence on Baldwin's fiction, despite Baldwin's fundamental complaint with Hemingway: his American innocence and "pastoral vision," 45 which Scruggs argues that Baldwin rewrites rather than discards. Aimee Pozorski considers the influence of another modernist-T. S. Eliot-on Baldwin's work, looking at drafts of an unpublished poem of Baldwin's in the Beinecke Library and speculating that Baldwin was affected by "a fear that his poem was too much influenced by Eliot," ${ }^{\prime 46}$ all the while deepening the inquiry into Baldwin's merits as a poet.

Other critics focus on Baldwin in conversation with his contemporaries, such as Eileen Barrett's essay on the complementary influence of Baldwin and Carson McCullers in ANQ. In an article in Renascence Carole Harris considers Baldwin and Flannery O'Connor in terms of their engagement with the South. Both authors, Harris argues, were "witness to white Southerners' nostalgia for the past and panic for the future at this moment of change," anti-segregation legislation. Baldwin's anxious forays into the South are viewed through an expansive context here, as O'Connor reveals in a letter that meeting Baldwin on her turf-which didn't happen-would have produced considerable anxiety for her and for her neighbors as well. Both authors critique southern culture, albeit from two radically different perspectives.

Douglas Taylor revisits the contentious relationship between Baldwin and both Norman Mailer and Eldridge Cleaver in terms of the intersection of race and masculinity. In his reading, the three authors initiate a tense conversation, but Baldwin's voice emerges as the prescient, lasting one: "in his exploration of the roles that fantasy and projection play in white men's imagining of the racial other, Baldwin moves in the direction of a psychoanalytic exploration of racial dynamics that still remains to be adequately developed within critical race theory." ${ }^{38}$ Nathaniel Mills takes the critical understanding of the vexed relationship between 
Baldwin and Cleaver yet further in a 2012 article, in particular reading Baldwin's If Beale Street Could Talk as an indirect response to Cleaver's homophobic screed; he writes,

Baldwin used Cleaver's attack as the occasion to work out a theory of black revolution and a self-theorization of black revolutionary art in Beale Street ... the ultimate political goal of Cleaver's brand of revolutionary nationalism - the total transformation of a racist, capitalist society—was one Baldwin also aspired to in the late $1960 \mathrm{~s}^{49}$

This willingness to reread such notorious public controversies as the row between Baldwin and Cleaver is also a way of addressing the critical misunderstanding of Baldwin's later work, for Mills argues that Beale Street is "not evidence of Baldwin's meek submission to the late-1960s radical turn in the black movement but of his creative and idiosyncratic participation in that turn." 50

Baldwin's place against the backdrop of a broader literary scene is the context for other critical articles on his work in conversation with that of his contemporaries. Molly Farneth considers the "striking similarities between the language of the expatriate Baldwin and that of the emerging ethics of French existentialism, especially as developed by Simone de Beauvoir,"51 even while acknowledging the ambiguity of the relationship between Baldwin and this emerging school of philosophical thought. In an article in English Literary History, Douglas Field addresses the role of a group of left-leaning editors who helped to shape Baldwin's early career. Field points out that Baldwin was not the only mid-century black author to diminish the importance of leftist politics on his early thinking, and this erasure has left a critical gap that needs to be addressed. The deep context he provides around this subject in this article goes a long way toward filling that gap. In some ways, Baldwin's distancing himself from the so-called New York Intellectuals of the 1940s was yet another act of expatriation and self-definition, and Field's analysis frames Baldwin's flight to Paris in an original way.

A third subgroup of analyses of Baldwin and other writers considers Baldwin's influence on the next generation, such as Matt Brim's essay in ANQ that begins with observations by Essex Hemphill. Naughton's article-discussed above-is at least partly about Baldwin's influence on Caryl Phillips. Courtney Thorsson examines Baldwin's influence on a trio of women writers-Gayl Jones, Gloria Naylor, and Toni Morrison-in terms of the way they translate his depiction of interracial relationships among men into renditions of intraracial relationships among women; Thorsson argues that these “women authors seize on Baldwin's language to depict a female coalescence that creates, defines, and also limits community." ${ }^{2}$ Mildred R. Mickle looks at Baldwin's work in conversation with novels by Octavia Butler and Tananarive Due to consider the way these authors use faith "to create a peaceful space in which history, mind, and body can meld and thrive." 53 The fiction writer Randall Kenan contributes an intriguing essay to the special issue of $A A R$ that deepens our collective understanding of Baldwin's meeting with the Swedish filmmaker Ingmar Bergman. Kenan reads outward from that event to 
produce a far-reaching essay that is part memoir, part biographical sketch, part film criticism, and part cultural analysis. In short, it is in its form and scope the kind of thing Baldwin himself would have written, and it is in the very capable hands of one of Baldwin's literary progeny.

The years 2010-13 are a watershed in Baldwin studies. In the interest of space, this essay could not be exhaustive, and there are a number of other excellent contributions to Baldwin scholarship published during this period, particularly with regard to gender and sexuality, which are ongoing subjects of interest in Baldwin studies. I should also acknowledge the artificiality of the categories I have identified here, for it could easily be said that certain critical inquiries belong in all four categories, or actually in none of them. Baldwin's own resistance to categorical labels echoes loudly as I conclude this overview, but nonetheless I see clear trends emerge that are the product of an ever-growing cadre of scholars who are in constant conversation. When I was first writing about Baldwin at the beginning of the twenty-first century, I had a haunting fear that my essay collection and Dwight McBride's might have saturated the market. It is all too clear now that these collections were just the beginning of a long, widespread, deep inquiry that is gathering steam annually. As the man himself once said, "Amen. En avant."54

\section{Notes}

1 Lynn Orilla Scott, "Trends in James Baldwin Criticism 2001-10," James Baldwin Review, 2 (2016), p. 168.

2 Gerald David Naughton, “The Whole Root is Somewhere in the Music': Jazz, Soul, and Literary Influence in James Baldwin and Caryl Phillips,” ARIEL, 44:2-3 (2013), p. 113.

3 Ibid., p. 113.

4 Carter Mathes, "The Mind is a Strange and Terrible Vehicle': Fractured Time and Multidimensional Sound in No Name in the Street," African American Review, 46:4 (2013), p. 593.

5 E. L. Kornegay, A Queering of Black Theology (New York, Macmillan, 2013), p. 6.

6 Ibid., p. 7.

7 Ibid., p. 146.

8 Koritha Mitchell, “James Baldwin, Performance Theorist, Sings the Blues for Mister Charlie," American Quarterly, 64:1 (2012), p. 43.

9 Soyica Diggs Colbert, The African American Theatrical Body: Reception, Performance, and the Stage (Cambridge, Cambridge University Press, 2011), p. 12.

10 Ibid., p. 163.

11 Ibid., p. 165.

12 Ibid., p. 192.

13 Shonni Enelow, "The Method and the Means: James Baldwin at the Actors Studio," Theatre Survey, 53:1 (2012), p. 86.

14 Ibid., p. 87.

15 Ryan Jay Friedman, “Enough Force to Shatter the Tale to Fragments': Ethics and Textual Analysis in James Baldwin's Film Theory," English Literary History, 77 (2010), p. 385. 
16 Ed Pavlić, "Speechless in San Francisco: Inter-viewing Films by Barry Jenkins and James Baldwin," Transition, 110 (2013), p. 119.

17 Brian Norman, "Bringing Malcolm X to Hollywood," in Robert Terrill (ed.), The Cambridge Companion to Malcolm X (Cambridge, Cambridge University Press, 2010), p. 40.

18 Ibid., p. 40.

19 Douglas Field, “'One Is Mysteriously Shipwrecked Forever, in the Great New World': James Baldwin from New York to Paris," in Jeremy Braddock and Jonathan P. Eburne (eds.), Paris, Capital of the Black Atlantic (Baltimore, MD, Johns Hopkins University Press, 2013), p. 177.

20 Cora Kaplan and Bill Schwarz (eds.), James Baldwin: America and Beyond (Ann Arbor, MI, University of Michigan Press, 2011), p. 4.

21 Magdalena Zaborowska, "From Istanbul to St.-Paul-de-Vence: Around James Baldwin's Welcome Table," in Kaplan and Schwarz (eds.), James Baldwin: America and Beyond, p. 204.

22 Kevin Birmingham, “History's Ass Pocket': The Sources of Baldwinian Diaspora," in Kaplan and Schwarz (eds.), James Baldwin: America and Beyond, p. 144.

23 Ibid., p. 153.

24 Cheryl A. Wall, "Stranger at Home: James Baldwin on What It Means to Be an American," in Kaplan and Schwarz (eds.), James Baldwin: America and Beyond, p. 37.

25 Colm Tóibín, "Baldwin and 'the American Confusion,"” in Kaplan and Schwarz (eds.), James Baldwin: America and Beyond, p. 56.

26 Vaughn Rasberry, “Now Describing You': James Baldwin and Cold War Liberalism,” in Kaplan and Schwarz (eds.), James Baldwin: America and Beyond, pp. 85-6.

27 George Shulman, "Baldwin, Prophecy, and Politics," in Kaplan and Schwarz (eds.), James Baldwin: America and Beyond, p. 108.

28 Robert Reid-Pharr, "Rendezvous with Life: Reading Early and Late Baldwin," in Kaplan and Schwarz (eds.), James Baldwin: America and Beyond, p. 128.

29 Kevin Gaines, "Exile and the Private Life," in Kaplan and Schwarz (eds.), James Baldwin: America and Beyond, p. 174.

30 Ibid., p. 175.

31 Douglas Field, "What Is Africa to Baldwin? Cultural Illegitimacy and the Stepfatherland," in Kaplan and Schwarz (eds.), James Baldwin: America and Beyond, p. 210.

32 Ibid., p. 223.

33 Rob Waters, “'Britain is No Longer White': James Baldwin as a Witness to Postcolonial Britain," African American Review, 46:4 (2013), p. 722.

34 Hortense Spillers, "A Transatlantic Circuit: Baldwin at Mid-Century," Callaloo, 35:4 (2012), p. 937.

35 Kim Fortuny, “James Baldwin's 1970 Turkish Interviews: 'The American Way of Life' and the Rhetoric of War from Vietnam to the Near and Middle East," Texas Studies in Literature and Language, 55:4 (2013), p. 435.

36 Nabile Fàres and Peter Thompson, “James Baldwin: A 1970 Interview," Transition, 105 (2011), p. 62.

37 Bill Lyne, "God's Black Revolutionary Mouth: James Baldwin’s Black Radicalism," Science and Society, 74:1 (2010), p. 14.

38 Ibid., p. 17. 
39 Shireen R. K. Patell, “'We the People,' Who? James Baldwin and the Traumatic Constitution of These United States," Comparative Literature Studies, 48:3 (2011), p. 357.

40 Ibid., p. 386.

41 Melinda Plastas and Eve Allegra Raimon, "Brutality and Brotherhood: James Baldwin and Prison Sexuality," African American Review, 46:4 (2013), p. 687.

42 D. Quentin Miller, "A Criminal Power": James Baldwin and the Law (Columbus, OH, Ohio State University Press, 2012), p. 166.

43 David W. Blight, American Oracle (Cambridge, MA, Harvard University Press, 2011), p. 187.

44 Ibid., p. 187.

45 Charles Scruggs, "Looking for a Place to Land," in Charles Scruggs (ed.), Hemingway and the Black Renaissance (Columbus, OH, Ohio State University Press, 2012), p. 64.

46 Aimee Pozorski, “The Influence of T.S. Eliot on James Baldwin's Poetry," ANQ: A Quarterly Journal of Short Articles, Notes, and Reviews, 24:4 (2011), p. 227.

47 Carole K. Harris, "On Flying Mules and the Southern Cabala: Flannery O'Connor and James Baldwin in Georgia," Renascence, 65:5 (2013), p. 327.

48 Douglas Taylor, "Three Lean Cats in a Hall of Mirrors: James Baldwin, Norman Mailer, and Eldridge Cleaver on Race and Masculinity," Texas Studies in Literature and Language, 52:1 (2010), pp. 70-1.

49 Nathaniel Mills, "Cleaver / Baldwin Revisited: Naturalism and the Gendering of Black Revolution," Studies in American Naturalism, 7:1 (2012), p. 72.

50 Ibid., p. 52.

51 Molly Farneth, "James Baldwin, Simone de Beauvoir, and the 'New Vocabulary' of Existentialist Ethics," Soundings: An Interdisciplinary Journal, 96:2 (2013), p. 170.

52 Courtney Thorsson, “James Baldwin and Black Women's Fiction,” African American Review, 46:4 (2013), p. 616.

53 Mildred R. Mickle, “Faith in Verse and Fiction: James Baldwin's, Phillis Wheatley's, Octavia E. Butler's, and Tananarive Due's Creation of a Peaceful Space," in Morris Dickstein (ed.), Critical Insights: James Baldwin (Pasadena, CA, Salem Press, 2011), p. 78.

54 James Baldwin, Notes of a Native Son (1955; Boston, Beacon Press, 1984).

\section{Works Cited}

Baldwin, James, Notes of a Native Son (1955; Boston, Beacon Press, 1984).

Birmingham, Kevin, “'History's Ass Pocket': The Sources of Baldwinian Diaspora," in Cora Kaplan and Bill Schwarz (eds.), James Baldwin: America and Beyond (Ann Arbor, MI, University of Michigan Press, 2011), pp. 141-58.

Blight, David W., American Oracle (Cambridge, MA, Harvard University Press, 2011).

Colbert, Soyica Diggs, The African American Theatrical Body: Reception, Performance, and the Stage (Cambridge: Cambridge University Press, 2011).

Dickstein, Morris (ed.), Critical Insights: James Baldwin (Pasadena, CA, Salem Press, 2011).

Enelow, Shonni, "The Method and the Means: James Baldwin at the Actors Studio," Theatre Survey, 53:1 (2012), pp. 85-103.

Fàres, Nabile, and Peter Thompson, "James Baldwin: A 1970 Interview," Transition, 105 (2011), pp. 62-73.

Farneth, Molly, "James Baldwin, Simone de Beauvoir, and the 'New Vocabulary' of Existentialist Ethics,” Soundings: An Interdisciplinary Journal, 96:2 (2013), pp. 170-88. 
Field, Douglas, "Interview with David Linx," African American Review, $46: 4$ (2013), pp. 731-40.

"James Baldwin's Life on the Left: A Portrait of the Artist as a Young New York Intellectual,” ELH, 78:4 (2011), pp. 833-62.

— "One Is Mysteriously Shipwrecked Forever, in the Great New World': James Baldwin from New York to Paris," in Jeremy Braddock and Jonathan P. Eburne (eds.), Paris, Capital of the Black Atlantic (Baltimore, MD, Johns Hopkins University Press, 2013), pp. 175-99.

"What Is Africa to Baldwin? Cultural Illegitimacy and the Step-fatherland," in Cora Kaplan and Bill Schwarz (eds.), James Baldwin: America and Beyond (Ann Arbor, MI, University of Michigan Press, 2011), pp. 209-28.

Fortuny, Kim, "James Baldwin's 1970 Turkish Interviews: 'The American Way of Life' and the Rhetoric of War from Vietnam to the Near and Middle East," Texas Studies in Literature and Language, 55:4 (2013), pp. 434-51.

Friedman, Ryan Jay, “Enough Force to Shatter the Tale to Fragments': Ethics and Textual Analysis in James Baldwin's Film Theory,” English Literary History, 77 (2010), pp. 385-411.

Gaines, Kevin, "Exile and the Private Life," in Cora Kaplan and Bill Schwarz (eds.), James Baldwin: America and Beyond (Ann Arbor, MI, University of Michigan Press, 2011), pp. 173-87.

Harris, Carole K., “On Flying Mules and the Southern Cabala: Flannery O'Connor and James Baldwin in Georgia," Renascence, 65:5 (2013), pp. 327-50.

Kaplan, Cora, and Bill Schwarz (eds.), James Baldwin: America and Beyond (Ann Arbor, MI, University of Michigan Press, 2011).

Kornegay, E. L., A Queering of Black Theology: James Baldwin's Blues Project and Gospel Prose (New York, Palgrave Macmillan, 2013).

Lyne, Bill, “God's Black Revolutionary Mouth: James Baldwin’s Black Radicalism," Science and Society, 74:1 (2010), pp. 12-36.

Mathes, Carter, "The Mind is a Strange and Terrible Vehicle': Fractured Time and Multidimensional Sound in No Name in the Street", African American Review, 46:4 (2013), pp. 587-604.

Mickle, Mildred R., "Faith in Verse and Fiction: James Baldwin's, Phillis Wheatley's, Octavia E. Butler's, and Tananarive Due's Creation of a Peaceful Space," in Morris Dickstein (ed.), Critical Insights: James Baldwin (Pasadena, CA, Salem Press, 2011), pp. 78-94.

Miller, D. Quentin, “A Criminal Power": James Baldwin and the Law (Columbus, OH, Ohio State University Press, 2012).

_Lost and ... Found? James Baldwin's Script and Spike Lee's Malcolm X," African American Review, 46:4 (2013), pp. 671-85.

Mills, Nathaniel, "Cleaver / Baldwin Revisited: Naturalism and the Gendering of Black Revolution,” Studies in American Naturalism, 7:1 (2012), pp. 50-79.

Mitchell, Koritha, "James Baldwin, Performance Theorist, Sings the Blues for Mister Charlie,” American Quarterly, 64:1 (2012), pp. 33-60.

Naughton, Gerald David, “The Whole Root is Somewhere in the Music': Jazz, Soul, and Literary Influence in James Baldwin and Caryl Phillips,” ARIEL, 44:2-3 (2013), pp. 113-39.

Norman, Brian, "Bringing Malcolm X to Hollywood," in Robert Terrill (ed.), The Cambridge Companion to Malcolm X (Cambridge, Cambridge University Press, 2010), pp. 39-50. 
Patell, Shireen R. K., “'We the People,' Who? James Baldwin and the Traumatic Constitution of These United States," Comparative Literature Studies, 48:3 (2011), pp. 356-87.

Pavlić, Ed, "Speechless in San Francisco: Inter-viewing Films by Barry Jenkins and James Baldwin," Transition, 110 (2013), pp. 102-19.

Plastas, Melinda, and Eve Allegra Raimon, "Brutality and Brotherhood: James Baldwin and Prison Sexuality," African American Review, 46:4 (2013), pp. 687-99.

Pozorski, Aimee, “The Influence of T.S. Eliot on James Baldwin's Poetry,” ANQ: A Quarterly Journal of Short Articles, Notes, and Reviews, 24:4 (2011), pp. 227-34.

Rasberry, Vaughn, “Now Describing You': James Baldwin and Cold War Liberalism," in Cora Kaplan and Bill Schwarz (eds.), James Baldwin: America and Beyond (Ann Arbor, MI, University of Michigan Press, 2011), pp. 84-105.

Reid-Pharr, Robert, "Rendezvous with Life: Reading Early and Late Baldwin," in Cora Kaplan and Bill Schwarz (eds.), James Baldwin: America and Beyond (Ann Arbor, MI, University of Michigan Press, 2011), pp. 126-38.

Scott, Lynn Orilla, "Trends in James Baldwin Criticism 2001-10," The James Baldwin Review, 2 (2016), pp. 168-96.

Scruggs, Charles, "Looking for a Place to Land," in Charles Scruggs (ed.), Hemingway and the Black Renaissance (Columbus, OH, Ohio State University Press, 2012), pp. 55-77.

Shulman, George, "Baldwin, Prophecy, and Politics," in Cora Kaplan and Bill Schwarz (eds.), James Baldwin: America and Beyond (Ann Arbor, MI, University of Michigan Press, 2011), pp. 106-25.

Spillers, Hortense, “A Transatlantic Circuit: Baldwin at Mid-Century," Callaloo, 35:4 (2012), pp. 929-37.

Taylor, Douglas, "Three Lean Cats in a Hall of Mirrors: James Baldwin, Norman Mailer, and Eldridge Cleaver on Race and Masculinity," Texas Studies in Literature and Language, 52:1 (2010), pp. 70-101.

Thorsson, Courtney, "James Baldwin and Black Women's Fiction," African American Review, 46:4 (2013), pp. 615-31.

Wall, Cheryl A., "Stranger at Home: James Baldwin on What It Means to Be an American," in Cora Kaplan and Bill Schwarz (eds.), James Baldwin: America and Beyond (Ann Arbor, MI, University of Michigan Press, 2011), pp. 35-52.

Waters, Rob, “'Britain is No Longer White': James Baldwin as a Witness to Postcolonial Britain,” African American Review, 46:4 (2013), pp. 715-30.

Zaborowska, Magdalena, "From Istanbul to St.-Paul-de-Vence: Around James Baldwin's Welcome Table," in Cora Kaplan and Bill Schwarz (eds.), James Baldwin: America and Beyond (Ann Arbor, MI, University of Michigan Press, 2011), pp. 188-208.

\section{Contributor's Biography}

D. Quentin Miller is professor and chair of English at Suffolk University in Boston. He is the author of "A Criminal Power": James Baldwin and the Law (Ohio State University Press, 2012), the editor of Re-Viewing James Baldwin: Things Not Seen (Temple University Press, 2000), and the author of more than two dozen articles and reference volume entries on Baldwin. His most recent book is The Routledge Introduction to African American Literature and his forthcoming books are American Literature in Transition: 1980-1990, Understanding John Edgar Wideman, and James Baldwin in Context. 